\title{
Management of poisoning: general protocol
}

\author{
Languluri Reddenna*, Tedlla Rama Krishna \\ Pharm-D, Intern, Department of Pharmacy Practice, P. Rami Reddy Memorial College of Pharmacy (Rajiv Gandhi Institute of \\ Medical Sciences), Utukur, Kadapa, Andhra Pradesh, India-516003 \\ *Corresponding author E-mail: reddennapharmd@gmail.com
}

\begin{abstract}
Poisons used for many purposes across the duration of human existence, most commonly as weapons, anti-venoms, and medicines. Poison had allowed much progress in branches, toxicology, and technology, among other sciences and discovered in ancient times, used by ancient tribes and civilizations as a hunting tool to quicken and ensure the death of their prey or enemies.Poisons are substances, whichcause disturbances to organisms, usually by chemical reaction or other activity on the molecular scale, when a sufficient quantity is absorbed by an organism. Poisons are of diverse natures because they are classified by origin, physical form, chemical nature, chemical activity, target site, or use. For example, it was estimated that deliberate ingestion of pesticides causes 370,000 deaths each year.Poison Control Centers answer questions about potential poisons in addition to providing treatment management advice about household products, medicines, pesticides, plants, bites and stings, food poisoning, and fumes.
\end{abstract}

Keywords: Management, poison, poisoning, poison control center.

\section{Introduction}

All over human history, intentional application of poison had used as a method of assassination, murder, suicide, and execution.[1][2] Many vernaculars describe lethal injection with their corresponding words for poison shot. Poison's lethal effect can combined with its apparently magical powers; an example is the Chinesegupoison. Poison also employed in gunpowder warfare. For example, the 14th century Chinese text of the Huolongjingwritten by Jiao Yu outlined the use of a poisonous gunpowder mixture to fill cast irongrenade bombs. [3] The history of poison [4] bounces from before $4500 \mathrm{BC}$ to the present day. Poisons used for many purposes across the duration of human existence, most commonly as weapons, anti-venoms, and medicines. Poison had allowed much progress in branches, toxicology, and technology, among other sciences and discovered in ancient times, used by ancient tribes and civilizations as a hunting tool to quicken and ensure the death of their prey or enemies. This use of poison grew more advanced, and many of these ancient peoples began forging weapons designed specifically for poison enhancement. Later in history, particularly at the time of the Roman Empire, one of the more prevalent uses was assassination. As early as 331 BC, poisonings executed at the dinner table or in drinks were reported, and the practice became a common occurrence. The use of fatal substances was grasped among every social class; even the nobility would often use it to dispose of unwanted political or economic opponents.In Medieval Europe, poison became a more popular form of killing, though cures surfaced for many of the more widely known poisons and stimulated by the increased availability of poisons; shops known as apothecaries, selling various medicinal wares, were open to the public and from there, substances that were traditionally used for curative purposes were employed for more sinister means. At the same time, other areas of the world were making great advances in terms of poison; Arabs had successfully made arsenic odorless and transparent, making assassinations impossible to detect. This "poison epidemic" was also prevalent in parts of Asia at this time, as well.Over the centuries, the use of poisons for scheming means and harmful purposes continued to escalate. The means for curing these poisons also continued to advance, but new poisons came up and became popular among criminals. In the present day, poisoning by harmful intent is less prevalent, and the risk of accidental poisoning now exists more in everyday substances and products. Moreover, its use has enlarged exponentially; poison is often used as a pesticide, disinfectant, cleaning solution, or preservative, among others. In spite of this, the first use of poison as a hunting tool remains in remote parts of developing countries, especially those in Africa, South America, and Asia. [5] 


\section{Poisons}

Poisons are substances, whichcause disturbances to organisms, usually by chemical reaction or other activity on the molecular scale, when a sufficient quantity is absorbed by an organism. The substances applied to the organs of the body, are capable of altering or destroying, in a majority of cases, some or all of the functions necessary to life, are called poisons. As per law, any substance, irrespective of its quality or quantity, when given with an intention to endanger, injure, or kill a person is called a poison. [6] The term poison concerning biology and chemistry is often misused due to lack of a universal definition. Biologically speaking, any substance if given in large enough amounts is poisonous and can cause death. [7]In the context of biology, poisons are substances that can cause disturbances to organisms,[8] usually by chemical reaction or other activity on the molecular scale, when a sufficient quantity is absorbed by an organism. In medicine and in zoology, a poison is distinguished from a toxin and a venom. Toxins are poisons produced via some biological function in nature and venoms are usually defined as biological toxins that are injected by a bite or sting to cause their effect, while other Poisons are generally defined as substances, which are absorbed through epithelial linings such as the skin or gut.The study of the symptoms, mechanisms, treatment and diagnosis of biological poisoning is known as toxicology.

\section{Classification}

Poisons are of diverse natures because they are classified by origin, physical form, chemical nature, chemical activity, target site, or use.

Microbial Poisons: Ex: Botulinum toxin.

AlkaloidalPoisons: (Plant Poisons): These poisons arenitrogenous plant principles, which produce their chief effect on some part ofthe central nervous system.Some examples areatropine, cocaine, morphine, strychnine, and hyoscyamine.Datura poisoning is the third commonest poisons in India. 'Datura' or thorn apple is common in India and the crushed seeds are administered in food and drink by criminals, with intent to rob rather than to kill.

Non-Alkaloidal Poisons: These poisons include various chemical compounds, some obtained from plants, having hypnotic, neurotic, and systemic effects.Someexamples are barbiturates, salicylates, digoxin, and turpentine.

Animal Poisons: Bites and stings of venomous terrestrial or marine animals, the prior group including poisonous snakes, scorpions, spiders, and ants, and the latter group including sea snakes, stingrays, and jellyfish.

Gaseous Poisons: These poisons are present in the gaseous stateand if inhaled, destroy the capability of the bloodas a carrier of oxygen and irritate or destroy thetissues of the air passages and lungs. When in contact with the skin and mucous membranes,gaseous poisons produce lacrimation, vesication,inflammation, and congestion. Examples are carbon monoxide, carbon dioxide, hydrogen sulfide,sulfur dioxide, ammonia gas, chlorine gas, andchemical warfare agents.

Inorganic Poisons: Inorganic poisons fall into two classes:

1) Corrosives rapidlydestroy or decompose the body tissues at pointof contact. Some examples are hydrochloric,nitric, and sulfuric acids; phenol; sodium hydroxide and iodine.

2) Metals and their salts, mainaction occurs after absorption when they damageinternal organs, especially those of excretion.Some examples are arsenic, antimony, copper,iron, lead, mercury, radioactive substances andtin.

Synthetic Poisons: Include pesticides, household cleaners, cosmetics, pharmaceuticals, and hydrocarbons.

1) Pesticides include acaricidaethat kill mites, insecticidethat kill insects, molluscicidethat kill molluscs, nematocidethat kill parasiticnematodes (roundworms), rodenticidethat kill rodents, herbicide that kills weeds.

2) Household cleaners include phenolic substances and acids.

3) Cosmetics include Hair Dyes (Ex: Super Vasmol 33), Perfumes and other Aerosols.

4) Pharmaceuticals include Pharmaceutical Drugs.

5) Hydrocarbons include Petrol and Kerosene products.[9], [10], [11], [12]

\section{$4 \quad$ Epidemiology}

It can be studied from different perspectives and include overall mortality, hospital admission rates, and enquiries to Poisons Information Services. Accidental poisoning is most common in children, but deliberate self-harm becomes predominant in teenage years and early adulthood [13]. Nearly one million people die each year because of suicide, and chemicals account for a significant number of these deaths. For example, it was estimated that deliberate ingestion of pesticides causes 370,000 deaths each year. The number of these deaths can be reduced by limiting the availability and access to highly toxic pesticides. Snakebite is a largely unrecognized public health problem that presents significant challenges for medical management. While reliable data are hard to obtain, it was estimated that about 5 million snake 
bites occur each year, resulting in up to 2.5 million envenoming, at least 100,000 deaths and around three times as many amputations and other permanent disabilities. A world directory of poisons centers (YellowTox) wasmaintained. Other activities include the provision of information on chemicals, the provision of information management tools, and the development of internationally peer-reviewed guidelines concerning the prevention and clinical management of poisoning. [14] Cosmetics, medicines, and other household items could lead to a serious poisoning if accidently consumed by children. The same danger potentially applies to an ointment that was intended to use externally and is accidently ingested.Each year in the U.S., there are over 2 million poisoning cases were reported. The home environment is the primary location of most poisonings, with over $90 \%$ of reported poisonings occurring at home. Most non-fatal poisonings occur in children younger than 6 years of age. The IPCS programme on poisoning prevention and management seeks to build capacity in countries to deal with these problems. An important area of activity is promoting the establishment and strengthening of poisons centers and work carried out under the IPCS INTOX Programme. [15].

\section{Clinical symptoms}

Table 1: Adverse health effects caused by selected classes of pesticides [16].

\begin{tabular}{|c|c|c|c|}
\hline Chemical/chemical class & Examples of pesticides & Clinical presentation & $\begin{array}{l}\text { Route of } \\
\text { exposure* }\end{array}$ \\
\hline Arsenicals & $\begin{array}{l}\text { Arsenic trioxide, CCA, } \\
\text { sodium arsenate }\end{array}$ & $\begin{array}{l}\text { Abdominal pain, nausea, vomiting, } \\
\text { garlic odour, metallic taste, bloody } \\
\text { diarrhoea, headache, dizziness, } \\
\text { drowsiness, weakness, lethargy, } \\
\text { delirium, shock, kidney insufficiency, } \\
\text { neuropathy }\end{array}$ & $\mathrm{O}, \mathrm{R}, \mathrm{D}$ (rarely) \\
\hline Borates (insecticide) & Boric acid, borax & $\begin{array}{l}\text { Upper airway irritation, abdominal } \\
\text { pain, nausea, vomiting, diarrhoea, } \\
\text { headache, lethargy, tremor, kidney } \\
\text { insufficiency }\end{array}$ & $\begin{array}{l}\mathrm{O}, \mathrm{R}, \mathrm{D} \text { (broken } \\
\text { skin) }\end{array}$ \\
\hline Carbamates (insecticide) & $\begin{array}{l}\text { Carbaryl, thiram, } \\
\text { aldicarb, mecarbam }\end{array}$ & $\begin{array}{l}\text { Malaise, weakness, dizziness, sweating, } \\
\text { headache, salivation, nausea, vomiting, } \\
\text { diarrhoea, abdominal pain, confusion, } \\
\text { dyspnea, dermatitis, pulmonary edema }\end{array}$ & $\mathrm{O}, \mathrm{D}$ \\
\hline $\begin{array}{l}\text { Chlorphenoxy } \\
\text { compounds(herbicides) }\end{array}$ & $\begin{array}{l}\text { Di/tri- } \\
\text { chlorophenoxyacetic } \\
\text { acid, MCPP }\end{array}$ & $\begin{array}{l}\text { Upper airway and mucous membrane } \\
\text { irritation, abdominal pain vomiting, } \\
\text { diarrhoea, tachycardia, weakness, } \\
\text { muscle spasm, coma, acidosis, } \\
\text { hypotension, ataxia, hypertonia, } \\
\text { seizures, dermal irritation, headache, } \\
\text { confusion, tachycardia }\end{array}$ & $\mathrm{O}, \mathrm{D}$ \\
\hline Calciferol (Rodenticide) & $\begin{array}{l}\text { Cholecalciferol, } \\
\text { ergocalciferol }\end{array}$ & $\begin{array}{l}\text { Fatigue, anorexia, weakness, headache, } \\
\text { nausea, polyuria, polydipsia, renal } \\
\text { injury, hypercalcemia }\end{array}$ & $\mathrm{O}$ \\
\hline Chloralose & Chloralose & $\begin{array}{l}\text { Vomiting, vertigo, tremor, myoclonus, } \\
\text { fasciculations, confusion, convulsions }\end{array}$ & $\mathrm{O}$ \\
\hline $\begin{array}{l}\text { Copper compounds } \\
\text { (fungicide) }\end{array}$ & $\begin{array}{l}\text { Copper acetate, copper } \\
\text { oleate }\end{array}$ & $\begin{array}{l}\text { Abdominal pain, vomiting, } \\
\text { skin/airway/mucous membrane } \\
\text { irritation, renal dysfunction, coma }\end{array}$ & $\mathrm{O}, \mathrm{R}, \mathrm{D}$ \\
\hline Coumarins (Rodenticide) & $\begin{array}{l}\text { Brodifacoum, warfarin, } \\
\text { pindone }\end{array}$ & $\begin{array}{l}\text { Echymoses, epistaxis, excessive } \\
\text { bleeding, haematuria, prolonged } \\
\text { prothrombin time, intracranial bleed, } \\
\text { anaemia, fatigue, dyspnea }\end{array}$ & $\mathrm{O}, \mathrm{D}$ (possible) \\
\hline $\begin{array}{l}\text { Diethyltoluamide (insect } \\
\text { repellent) }\end{array}$ & $\begin{array}{l}\text { DEET (N,N-diethyl- } \\
\text { meta-toluamide) }\end{array}$ & $\begin{array}{l}\text { Dermatitis, ocular irritation, headache, } \\
\text { restlessness, ataxia, confusion, seizures, } \\
\text { urticaria }\end{array}$ & $\mathrm{O}, \mathrm{D}$ \\
\hline Dipyridil (herbicide) & Paraquat, diquat & $\begin{array}{l}\text { Mucous membrane and airway } \\
\text { irritation, abdominal pain, diarrhoea, } \\
\text { vomiting, gastrointestinal bleeding, } \\
\text { pulmonary edema, dermatitis, renal and }\end{array}$ & $\begin{array}{l}\mathrm{O}, \mathrm{D} \text { (via broken } \\
\text { skin) }\end{array}$ \\
\hline
\end{tabular}




\begin{tabular}{|c|c|c|c|}
\hline & & hepatic damage, coma, seizures & \\
\hline Phosphonates (herbicide) & Roundup, glyphosate & $\begin{array}{l}\text { Airway, skin, and mucous membrane } \\
\text { irritation, abdominal, pain, nausea, } \\
\text { vomiting, shock, dyspnea, respiratory } \\
\text { failure }\end{array}$ & $\mathrm{O}, \mathrm{R}$ \\
\hline Fluoroacetate (Rodenticide) & Sodium fluoroacetate & $\begin{array}{l}\text { Vomiting, paresthesias, tremors, } \\
\text { seizures, hallucinations, coma, } \\
\text { confusion, arrhythmias, hypertension, } \\
\text { cardiac failure }\end{array}$ & $\mathrm{O}, \mathrm{D}$ (possible) \\
\hline $\begin{array}{l}\text { Mercury, organic } \\
\text { (fungicide) }\end{array}$ & Methyl mercury & $\begin{array}{l}\text { Metallic taste, paresthesias, tremor, } \\
\text { headache, weakness, delirium, ataxia, } \\
\text { visual changes, dermatitis, renal } \\
\text { dysfunction }\end{array}$ & $\mathrm{O}, \mathrm{R}, \mathrm{D}$ \\
\hline $\begin{array}{l}\text { Metalphosphides } \\
\text { (Rodenticide, fumigant) }\end{array}$ & $\begin{array}{l}\text { Zinc-, aluminium-, } \\
\text { magnesium- phosphide }\end{array}$ & $\begin{array}{l}\text { Abdominal pain, diarrhoea, acidosis, } \\
\text { shock, jaundice, paresthesias, ataxia, } \\
\text { tremors, coma, pulmonary edema, } \\
\text { tetany, dermal irritation }\end{array}$ & $\mathrm{O}, \mathrm{R}, \mathrm{D}$ \\
\hline Halocarbons (fumigant) & $\begin{array}{l}\text { Cellfume, Methyl } \\
\text { bromide }\end{array}$ & $\begin{array}{l}\text { Skin/airway/mucous membrane irritant, } \\
\text { cough, renal dysfunction, confusion, } \\
\text { seizures, coma, pulmonary edema }\end{array}$ & $\mathrm{O}, \mathrm{R}, \mathrm{D}$ \\
\hline $\begin{array}{l}\text { Nitrophenolic and } \\
\text { nitrocresolic herbicides }\end{array}$ & $\begin{array}{l}\text { Dinitrophenol, } \\
\text { dinitrocresol, dinoseb, } \\
\text { dinosarn }\end{array}$ & $\begin{array}{l}\text { Sweating, fever, confusion, malaise, } \\
\text { restlessness, tachycardia, yellow skin } \\
\text { staining, seizures, coma, renal } \\
\text { insufficiency, hepatic damage }\end{array}$ & $\mathrm{O}, \mathrm{R}, \mathrm{D}$ \\
\hline $\begin{array}{l}\text { Organochlorines } \\
\text { (insecticide) }\end{array}$ & $\begin{array}{l}\text { Aldrin, dieldrin } \mathrm{HCB} \text {, } \\
\text { endrin, lindane }\end{array}$ & $\begin{array}{l}\text { Cyanosis, excitability, dizziness, } \\
\text { headache, restlessness, tremors, } \\
\text { convulsions, coma, paresthesias, } \\
\text { nausea, vomiting, confusion, tremor, } \\
\text { cardiac arrhythmias, acidosis }\end{array}$ & $\mathrm{O}, \mathrm{R}, \mathrm{D}$ \\
\hline $\begin{array}{l}\text { Organophosphates } \\
\text { (insecticides) }\end{array}$ & $\begin{array}{l}\text { Malathion, parathion, } \\
\text { dichlorvos, chlorpyrifos }\end{array}$ & $\begin{array}{l}\text { Headache, dizziness, bradycardia, } \\
\text { weakness, anxiety, excessive sweating, } \\
\text { fasciculations, vomiting, diarrhoea, } \\
\text { abdominal cramps, dyspnea, miosis, } \\
\text { paralysis, salivation, tearing, ataxia, } \\
\text { pulmonary edema, acetylcholinesterase } \\
\text { inhibition, confusion }\end{array}$ & $\mathrm{O}, \mathrm{D}$ \\
\hline Organotin (fungicide) & $\begin{array}{l}\text { Fentin acetate, fentin } \\
\text { chloride }\end{array}$ & $\begin{array}{l}\text { Airway, skin, and mucous membrane } \\
\text { irritation, dermatitis, salivation, } \\
\text { delirium, headache, vomiting, dizziness }\end{array}$ & $\mathrm{O}, \mathrm{R}, \mathrm{D}$ \\
\hline $\begin{array}{l}\text { Phenol derivatives } \\
\text { (Fungicide, wood } \\
\text { preservative) }\end{array}$ & $\begin{array}{l}\text { Pentachlorophenol, } \\
\text { dinitrophenol }\end{array}$ & $\begin{array}{l}\text { Skin, airway, and mucous membrane } \\
\text { irritation, contact dermatitis, dyspnea, } \\
\text { diaphoreses, urticaria, tachycardia, } \\
\text { headache, abdominal pain, fever, } \\
\text { tremor }\end{array}$ & $\mathrm{O}, \mathrm{R}, \mathrm{D}$ \\
\hline Triazines (herbicide) & Atrazine, prometryn & $\begin{array}{l}\text { Mucous membrane, ocular and dermal } \\
\text { irritation }\end{array}$ & $\mathrm{O}, \mathrm{R}, \mathrm{D}$ \\
\hline Pyrethrins, Pyrethroids & $\begin{array}{l}\text { Allethrin, cyfluthrin, } \\
\text { permethrin }\end{array}$ & $\begin{array}{l}\text { Allergic reactions, anaphylaxis, } \\
\text { dermatitis, paresthesias, wheezing, } \\
\text { seizures, coma, pulmonary edema, } \\
\text { diarrhoea, abdominal pain }\end{array}$ & $\mathrm{R}, \mathrm{D}$ \\
\hline Thallium (Rodenticide) & Thallium sulfate & $\begin{array}{l}\text { Abdominal pain, nausea, vomiting, } \\
\text { bloody diarrhoea, headache, weakness, } \\
\text { liver injury, hair loss, paresthesias, } \\
\text { neuropathy, encephalopathy, cardiac } \\
\text { failure }\end{array}$ & $\mathrm{O}$ \\
\hline Strychnine (Rodenticide) & Strychnine & $\begin{array}{l}\text { Muscle rigidity, opisthotonus, } \\
\text { rhabdomyolysis }\end{array}$ & $\mathrm{O}$ \\
\hline
\end{tabular}

CCA: chromated copper arsenate; HCB: hexachlorobenzene; MCPP: methyl chlorphenoxy propionic acid. *Route of exposure key: O-oral/ingestion; $\mathrm{R}$ - respiratory/inhalation; D-dermal or ocular 


\section{First aid procedures for poisoning}

Swallowed Poisons: Do not give the victim anything to eat or drink before calling the Poison Center or a doctor. Do not make the victim throw-up or give ipecac syrup unless a doctor or the Poison Center instructs.

Inhaled Poisons: Get the victim to fresh air right away. Call the poison center.

Poisons on the Skin: Remove contaminated clothing and rinse the victim's skin with water for 10 minutes. Call the poison center.

Poisons in the Eye: Flush the victim's eye for 15 minutes using lukewarm water held 2-4 inches from the eye. Have the victim blink as much as possible while rinsing the eye. Never force the eyelid open. Call the poison center. [17]

Diagnosis of poisoning:

1) In the living:

- If the onset of symptoms is sudden- usually after a meal, drink, or a dose of medicine. The patient's habits, working conditions, daily activities will be analyzed.

- Sometimes symptoms are uniform in character and rapidly increase in severity followed by death or early recovery. One poison may be neutralized by other or increase the potency of other. For example, barbiturate with alcohol.

- Persons taking same food displaying same symptoms.

- Detection of poison in the food, medicine, vomits, urine, or stool.

2) In the dead:

a) Post mortem appearance

- External Examination - odour, stain, skin condition

- Internal Examination - Hyperaemea (redness of mucus), softening, ulceration, perforation

b) Chemical analysis - Urine, blood, stains, viscera

c) Moral and circumstantial evidence

\section{General treatment of poisoning:}

1) Removal of unabsorbed poison - cleaning, suction, stomach wash

2) Antidote for neutralizing absorbed poison - activated charcoal, chelates

3) Removal of absorbed poison and its intermediary substances - catharsis, enema

4) Symptomatic relief

\section{Poison management}

Initial management for all poisonings includes ensuring adequate cardiopulmonary function and providing treatment for any symptoms such as seizures, shock, and pain.Poisons that have been injected (e.g. from the sting of poisonous animals) can be treated by binding the affected body part with a pressure bandage and by placing the affected body part in hot water (with a temperature of $50^{\circ} \mathrm{C}$ ). The pressure bandage makes sure the poison is not pumped throughout the body and the hot water breaks down the poison. This treatment only works with poisons that are composed of proteinmolecules [18].

\section{Decontamination}

If the toxin was recently ingested, absorption of the substance may be able to be decreased through gastric decontamination. This may be achieved using activated charcoal, gastric lavage, whole bowel irrigation, or nasogastric aspiration. Routine use of emetics (syrup of Ipecac), cathartics or laxatives are no longer recommended.Activated charcoal is the treatment of choice to prevent absorption of the poison. It is usually administered when the patient is in the emergency room or by a trained emergency healthcare provider. However, charcoal is ineffective against metals such as sodium, potassium, and lithium, and alcohols and glycols; it is also not recommended for ingestion of corrosive chemicals such as acids and alkalis.[19]Whole bowel irrigation cleanses the bowel, this is achieved by giving the patient large amounts of a polyethylene glycol solution. The osmotically balanced polyethylene glycol solution is not absorbed into the body, having the effect of flushing out the entire gastrointestinal tract. Its major uses for ingestion of sustained release drugs, toxins that are not absorbed by activated charcoal (i.e. lithium, iron), and for the removal of ingested packets of drugs (body packing/smuggling).[20]Gastric lavage, commonly known as a stomach pump, is the insertion of a tube into the stomach, followed by administration of water or saline down the tube. The liquid is then removed along with the contents of the stomach. Lavage used for many years as a common treatment for poisoned patients. However, a recent review of the procedure in poisonings suggests no benefit.[21]Nasogastric aspiration involves the placement of a 
tube via the nose down into the stomach, the stomach contents are then removed via suction. This procedure is mainly used for liquid ingestions where activated charcoal is ineffective, e.g. ethylene glycol poisoning.Emesis (i.e. induced by ipecac) is no longer recommended in poisoning situations, because vomiting is ineffective at removing poisons.[22]Cathartics were postulated to decrease absorption by increasing the expulsion of the poison from the gastrointestinal tract. There are two types of cathartics used in poisoned patients; saline cathartics (Sodium sulfate, Magnesium citrate, Magnesium sulfate) and saccharide cathartics (Sorbitol). They do not appear to improve patient outcome and are no longer recommended [23].

\section{General protocol for the management of various poisons}

Protocol for the management of super vasmol poisoning:

Super Vasmol 33 $3^{\mathrm{TM}}$ is an emulsion based hair dye commonly used in India.

Common name: Vasmol.

Ingredients: Paraphenylenediamine $(<4 \%)$, resorcinol, propylene glycol, liquid paraffin, cetostearyl alcohol, sodium lauryl sulfate, EDTA sodium, herbal extracts and preservatives and perfumes.Some of these ingredients like paraphenylene diamine and resorcinol are known toxicants with multi-organ effects, while the toxicity profiles of others are not known.

\section{Clinical features of poisoning}

Accidental or suicidal ingestion of PPD causes systemic toxicity, manifested by severe edema of neck and face and laryngeal edema with respiratory distress frequently requiring emergency tracheostomy and mechanical ventilation. It also causes rhabdomyolysis and acute renal failure, results in death if not treated aggressively.

Other symptoms include:

1) Angioneurotic edema.

2) Intravascular hemolysis.

3) Hemoglobinuria.

4) Asphyxia and respiratory failure.

5) Severe hypocalcemia and hyperuricemia.

6) Hyperkalemia.

7) Myoglobinuria.

8) Myocarditis and Arrhythmias leading to sudden death

Resorcinol: Resorcinol is a Phenolic chemical used in photography, tanning and cosmetics (hair dye) industry. It is also a pharmaceutical agent used topically in skin diseases. Resorcinol is a moderately toxic and corrosive chemical. After oral administration, resorcinol is readily absorbed from the gastrointestinal tract, metabolized, and excreted by male and female rats, indicating little potential for bioaccumulation in animal tissues. It is known to cause eye, skin, oral and gastrointestinal injuries. Systemic toxicity is manifested as vomiting, dyspnea, methemoglobinemia, hypothermia, tachypnea, pallor, profuse sweating. Hypotension and tachycardia. [24]

Other symptoms include:

1) Renal \& Neuro toxicity.

2) Pulmonary edema, bronchospasm.

3) Seizures followed by CNS depression.

Clinical manifestations:

1) Respiratory.

2) Musculoskeletal.

3) Renal manifestations.

Characteristic triad of features encountered.

1) Early angioneurotic edema with stridor.

2) Rhabdomyolysis with chocolate colored urine.

3) Acute renal failure.

General symptoms [25]:

1) Abdominal Pain.

2) Vomiting.

3) Diarrhoea (watery, bloody).

4) Burning pain in throat.

5) Breathing difficulty.

6) Burns to the eye.

7) Blurred vision.

8) Arrhythmias.

9) Shock. 
10) Slurred speech.

11) Stupor.

12) Coma.

\section{Mechanism of rhabdomyolysis [26]}

Rhabdomyolysis means destruction or disintegration of striated muscle. This syndrome is characterized by muscle breakdown and necrosis resulting in the leakage of the intracellular muscle constituents into the circulation and extracellular fluid. Rhabdomyolysis ranges from an asymptomatic illness with elevation in the creatine kinase (CK) level to a life threatening condition associated with extreme elevations in CK, electrolyte imbalances, acute renal failure (ARF) and disseminated intravascular coagulation. The cause of rhabdomyolysis is easily identified; however, in some instances the etiology is elusive. Muscular trauma is the most common cause of rhabdomyolysis. Less common causes include muscle enzyme deficiencies, electrolyte abnormalities, infectious causes, drugs, toxins and endocrinopathies. Rhabdomyolysis is commonly associated with myoglobinuria, and if this is sufficiently severe, it can result in ARF. Weakness, myalgia and tea-colored urine are the main clinical manifestations. The most sensitive laboratory finding of muscle injury is an elevated CK level. In the absence of myocardial or brain infarction, CK > 5000 U/l indicates serious muscle injury. The management of patients with rhabdomyolysis includes advanced life support (airway, breathing and circulation) followed by measures to preserve renal function, the latter includes vigorous hydration. The use of alkalizing agents and osmotic diuretics, while commonly used, remains of unproven benefit.

\section{Treatment}

1) Medical emergency.

2) Gastric lavage.

3) Monitor for respiratory distress.

4) Endotracheal intubation early if laryngeal edema develops.

5) Metabolic acidosis.

6) Half normal saline and soda bicarbonate infusion.

7) Dialysis.

8)

\subsection{Protocol for the management of kerosene poisoning}

Toxic content: Hydrocarbon

Clinical features of poisoningCoughing, choking, fever, tachypnea, grunting, cyanosis, wheezing, head ache, dizziness, lethargy, ataxia, seizures, coma, gastro intestinal findings, nausea, vomiting, abdominal pain and arrhythmias.

Treatment

1) Stabilization of the air way is always the first priority of treatment.

2) Give supplemental oxygen to all patients, and perform bedside pulse oximetry.

3) Early intubation, mechanical ventilation, and use of positive end-expiratory pressure may be warranted in a patient in whom oxygenation is inadequate or in a patient who has severe respiratory distress or a decreased level of consciousness.

4) Take all precautions to minimize the patients risk of vomiting and further aspiration.

5) A trial of bronchodilators may prove useful in patients with suspected bronchospasm.

A major complication of hydrocarbon poisoning is aspiration. Gastric lavage is indicated in large intentional ingestions. Air way must be stabilized to minimize the risk of aspiration secondary to vomiting and nasogastric lavage is preferred. Never induce emesis.

Antidote treatment: No specific Antidote.

\subsection{Protocol for the management of acid poisoning}

Types of Acids: Acetic acid, Formic acid, Hydrochloric acid, Hydrofluoric acid, Nitric acid, Sulfuric acid and Phosphoric acid.

\section{Clinical features of poisoning}

1) Significant acid ingestion produces immediate pain in the mouth, pharynx and abdomen.

2) Other early symptoms associated with the gastrointestinal injury may include intense thirst, pain on swallowing, drooling of saliva, vomiting, haematemesis and melena. 
3) Non -gastrointestinal symptoms may include stridor and hoarse voice. Inspection of the oropharynx may reveal areas of superficial burn that appear white or yellow and /or areas of deeper burn which appear grey or black and bleed easily.

4) Severe burns from acid ingestion may be associated with the life threatening acute complication of esophageal, gastric or intestinal perforation. Esophageal perforation is associated with chest pain, dyspnea, fever, subcutaneous emphysema of the chest or neck and a pleural rub. Perforation of the stomach or small intestine is associated with clinical features of chemical peritonitis: fever, abdominal tenderness, guarding and rebound ileus. Septic shock, multiorgan failure and death may complicate perforation.

Treatment

1) Initial management is primarily supportive. Particular attention should be directed to securing the airway, fluid resuscitation and provision of opoid analgesia.

2) Supportive care includes maintenance of adequate analgesia, fluid, electrolyte and $\mathrm{pH}$ balance, nutritional support, and monitoring for the development of complication. Parentral nutrition is necessary in more severe cases.

3) Patients' with deep discrete or circumferential ulceration or multiple ulcerations and /or areas of necrosis require more intensive supportive care and total parentral nutrition or a feeding jejunostomy until healing is documented. Patients with endoscopic findings of edema, erythema, superficial ulceration, blistering or erosions may be fed orally.

4) Urgent laparotomy (without associated thoracotomy) with surgical resection of necrotic tissue and surgical repair is indicated in the presence of symptoms or signs of gastrointestinal perforation or where full thickness necrosis is found at endoscopy.

5) Corticosteroids are not indicated, Broad-spectrum prophylactic antibiotics are not indicated unless there is evidence of gastrointestinal tract perforation or full thickness necrosis.

6) Do not give oral fluids; do rinse the mouth with water or saline.

\section{Decontamination}

1) Do not induce vomiting and do not attempt neutralization.

2) Do not give activated charcoal, as it will interfere with endoscopic evaluation.

Antidote treatment: No specific antidote

Bleaching powder poisoning

Toxic content

1) Ala-Sodium hypo chlorite

2) Bleaching Powder-Calcium hypochlorite (Chlorinated lime)

\section{Clinical Features of Poisoning}

Gastrointestinal irritation, with nausea, vomiting and diarrhea, is very common with ingestion of sodium hypochlorite solution. Hematemesis may occur with concentrated solutions. Household bleaches are unlikely to cause severe irritation unless contact is prolonged or the amount ingested is large. Severe esophageal damage may occur from ingestion of bleach, but several reports have concluded that it is not common.

Treatment:

1) Emesis was not recommended because of the risks associated with re-exposure of the esophagus to the bleach. In the majority of cases the only treatment necessary is plenty of fluids, especially milk. Less than $5 \mathrm{ml} / \mathrm{kg}$ oral ingestion of a $7 \%$ solution is unlikely to cause severe effects.

2) Where a concentrated or highly alkaline solution has been ingested or the quantity swallowed is thought to be large, nasogastric aspiration of the stomach contents should be considered. Monitor the pH, Sodium (sodium hypochlorite) / calcium (chlorinated lime) and chloride in severe cases. Symptomatic and supportive care with IV fluids for hypotension.

Decontamination:Emesis is not recommended because of the risk associated with re-exposure of the esophagus to the bleach.

Antidote treatment:No specific Antidote.

\subsection{Protocol for the management of dapsone poisoning}

\section{Clinical Features of poisoning}

Methaemoglobinaemia is the principal and constant feature of Dapsone poisoning. Clinical features may include headache, dizziness, agitation, restlessness, nausea, vomiting, abdominal pain, bluish-grey cyanosis, tachycardia, hyperventilation, stupor, convulsions, coma, jaundice and intravascular haemolysis.

Treatment:

1) Monitor blood pressure, respiration and urine output.

2) Oxygen therapy is indicated if there are clinical signs of Methaemoglobinaemia. 
3) Methylene blue is indicated when Methaemoglobinaemia is present. A dose of 1 to $2 \mathrm{mg} / \mathrm{kg}$ intravenously is administered over a few minutes and may be repeated every 4 hours as needed. Because of the relapsing course of Methaemoglobinaemia due to the long half-life of Dapsone, repeated administration of Methylene blue is sometimes necessary. Monitoring of methaemoglobin is mandatory for adjustment of the infusion rates: cyanosis is an unreliable guide especially when anaemia is also present and Methylene blue may cause a bluish-grey discoloration of the skin. Methylene blue therapy should be continued until the methaemoglobin level is below $10 \%$.

4) Supportive measures include treatment of respiratory failure, shock, acid-base disturbances and convulsions. Decontamination:

Repeated doses (20g 4 times a day) of oral activated charcoal are indicated because it enhances the total body clearance and elimination of Daps one and its principle toxic metabolite, monodactyl Daps one.

Elimination: Forced diuresis, Hemodialysis, Charcoal hem perfusion is beneficial.

Antidote treatment: There is no specific antidote.

\subsection{Protocol for the management of datura stramonium poisoning}

Common names: Jimson weed, Thorn apple.

Toxic content: Tropane alkaloids

Clinical features of poisoning

Mydriasis, cyclopedia, flushed warm dry skin, dry mouth, ileus, urinary retention, tachycardia, hyper or hypotension, delirium with hallucinations, jerky, myoclonic movements, choreoathetosis, hyperthermia, coma, respiratory arrest, rare seizures and central stimulation followed by depression.

\section{Treatment:}

1) If the patient presents with stupor or coma, treatment may include dextrose, thiamine, naloxone, etc. Otherwise the main component of management is support and observation.

2) The patient should be placed in a non-stimulating environment and monitored with frequent vital signs. A cooling blanket can be used for hyperthermia. The patient may require bladder catheterization for urinary retention.

\section{Decontamination:}

1) Decontamination should be considered even hours after ingestion secondary to the anticholinergic properties, which may delay the gastric emptying and absorption of the vegetable matter. Lavage has been proposed upto 48 hours after ingestion secondary to delayed gastric emptying.

2) Activated charcoal is an effective alternative to lavage in preventing further drug absorption and should be given with a cathartic if no ileus is present.

\section{Elimination:}

Multidose activated charcoal and Hemodialysis are considered effective, although Haddad has speculated that multidose activated charcoal may decrease continued, delayed absorption secondary to the decreased GI motility. Hemodialysis and forced diuresis may not enhance the elimination of atropine.

\section{Antidote treatment:}

Physostigmine:

Its use as a cholinergic agent in Datura poisoning is controversial and is generally reserved for life-threatening, intractable, anticholinergic effects including hypertension, seizures, unstable tachycardia, hyperthermia or pronounced hallucinations unresponsive to other agents.

Adult- $2 \mathrm{mg}$ as slow IV push, or $0.02 \mathrm{mg} / \mathrm{kg}$ repeated every 20 to $30 \mathrm{mins}$.

Onset of action is within 3-8 mins, duration is 30-60 minutes, and elimination half- life is 15-40 mins.

Atropine $(0.5 \mathrm{mg} / 1 \mathrm{mg}$ Physostigmine given in the last dose) should be available for reversal of symptoms of cholinergic excess from the Physostigmine such as bradycardia, heart block, or excessive secretions.

Children: The dose is $0.5 \mathrm{mg}$ every 5 minutes to a maximum total of $2 \mathrm{mg}$

\subsection{Protocol for the management of nerium oleander seed poisoning}

Common Name: Oleander.

Content: The main poisonous principles are cardiac glycosides like oleandrin, oleandrigenin, digitoxigenin etc.

\section{Clinical features of poisoning}

Malaise, vomiting, abdominal pain, bradycardia, dizziness, tremor, drowsiness, ataxia. The triad of gastrointestinal distress and cardiac dysrhythmia should alert to the possibility of oleander poisoning.

Treatment:

Life supportive procedures and symptomatic/specific treatment: 
1) Management depends on the occurrence of cardiac effects .Bradycardia may require atropine or electrical pacing.

2) Ventricular arrhythmias could be treated with phenytoin or lignocaine. Phenytoin should be infused intravenously slowly in doses of 3.5 to $5.0 \mathrm{mg} / \mathrm{kg}$, at a rate not greater than $50 \mathrm{mg} / \mathrm{minute}$ to repeat once if necessary. Lignocaine may be administered at a dose of $1 \mathrm{mg} / \mathrm{kg}$ as a slow intravenous bolus followed by continuous infusion of 2 $4 \mathrm{mg} / \mathrm{minute}$ (adult). The maximum dose of Phenytoin should not exceed $10 \mathrm{mg} / \mathrm{kg} / \mathrm{day}$.

3) Treatment of hyperkalemia should aim at lowering the serum potassium level with insulin, glucose, sodium bicarbonate and ion-exchange resins. Hemoperfusion may be considered in severe cases. Calcium chloride is contraindicated.

\section{Decontamination}

Emesis or gastric lavage is indicated at an early stage if the patient has not vomited copiously .It should be followed by the administration of activated charcoal and possibly a cathartic.

Elimination

Forced diuresis, hemoperfusion and Hemodialysis are not effective in increasing digoxin elimination.

Antidote treatment: Digoxin specific Fab antibody fragments can be considered when Oleander poisoning is unresponsive to conventional treatment.

\subsection{Protocol for the management of phenyl poisoning [27] [28]}

Toxic Content: Lysol (Cresol in soap solution)

Clinical features of poisoning

Ingestion produces burning pain and white necrotic lesions in the mouth, esophagus and stomach, vomiting and bloody diarrhea. Headache, dizziness, hypotension, ventricular arrhythmia, shallow respiration, cyanosis, pallor, excitation and convulsions may occur initially, but it is quickly followed by unconsciousness. A fall in body temperature and pulmonary edema may occur. Methemoglobinemia and hemolytic anemia have been reported occasionally.

\section{Treatment}

1) Make a proper assessment of airway, breathing, circulation and neurological status.

2) Maintain a clear airway.

3) If unconscious give artificial respiration.

4) If the patient has breathing difficulties, put them in a sitting position.

5) Monitor vital signs.

6) Monitor blood pressure and ECG.

7) Monitor fluid and electrolyte balance.

8) Monitor acid-base balance.

9) Control cardiac dysrhythmias with appropriate drug regimen.

10) Control convulsions with appropriate drug regimen.

\section{Decontamination:}

1) Remove and discard contaminated clothing.

2) Irrigate exposed eyes with copious amounts of water.

3) Wash skin with copious amounts of water or preferably if available wash with polyethylene glycol molecular weight 300 (Macrogol 300), isopropyl alcohol, industrial methylated spirit (PEG 3550) for at least 30 minutes.

4) Do not induce vomiting, empty stomach by aspiration followed by polyethylene glycol or activated charcoal with cathartic.

\section{Elimination}

If acute renal failure occurs in phenol poisoning, dialysis should probably not be used alone, but in conjunction with charcoal hemoperfusion. Without renal failure the use of charcoal hemoperfusion may also be useful.

Antidote treatment:No specific antidote

\section{Poison information center:}

A poison control center (PCC) or poison information center (PIC) is a medical information center that is able to provide immediate, free, and expert treatment advice and assistance over any form (Ex: telephone, etc.,) in case of exposure to poisonous or hazardous substances. [29] Poison Control Centers answer questions about potential poisons in addition to providing treatment management advice about household products, medicines, pesticides, plants, bites and stings, food poisoning, and fumes. More than $75 \%$ [30] of poison exposure cases are managed simply by phone, greatly reducing the need for costly emergency room and doctor visits.[31]In most countries around the world poison control centers can be reached toll-free, 24 hours a day, 7 days a week, 365 days a year. The WHO maintains a worldwide directory.Most countries have a poison control center with staffing similar to the American centers. A worldwide directory of poison centers is available from the World Health Organization's website. [32] 


\section{References}

[1] Kautilya suggests employing means such as seduction, secret use of weapons, poison etc. S.D. Chamola, Kautilya Arthshastra and the Science of Management: Relevance for the Contemporary Society, p. 40. ISBN 8178711265.

[2] Kautilya urged detailed precautions against assassination-tasters for food elaborate ways to detect poison. "Moderate Machiavelli? Contrasting the Prince with the Arthashastra of Kautilya". Critical Horizons, vol. 3, no. 2 (September 2002). Brill Academic Publishers. ISSN 1440-9917 (Print) 1568-5160 (Online). DOI: 10.1163/156851602760586671.

[3] Needham, Joseph (1986). Science and Civilization in China: Volume 5, Part 7. Taipei: Caves Books, Ltd. Page 180.

[4] Poison is defined as a "substance that causes death or injury when swallowed or absorbed." Colins Dictionaries, from the Bank of English (2001). Collins English Dictionary. HarperCollins. p. 594. ISBN 0007666918.

[5] "History of Poison". http://en.wikipedia.org/wiki/History_of_poison. Retrieved 2011-09-02.

[6] "Poison". http://hanumant.com/MJ-Poison.html. Retrieved 2011-09-02.

[7] "Poison". http://en.wikipedia.org/wiki/Poison. Retrieved 2011-09-02.

[8] "Poison" at Dorland's Medical Dictionary

[9] “Classification of poisons". http://www.mymedicenter.com/first-aid/poisoning/classification-based-on-origin.html. Retrieved 2011-09-02.

[10] "Classification of Poisons". http://www.tpub.com/content/medical/10669-c/css/10669-c_280.html. Retrieved 2011-09-02.

[11] "Datura Poisoning". http://www.onlinebangalore.com/heal/tips/datura.html. Retrieved 2011-09-02

[12] “Types of Poison”. http://en.wikipedia.org/wiki/List_of_types_of_poison. Retrieved 2011-09-02.

[13] "Epidemiology of Poisoning”. http://www.medicinejournal.co.uk/article/S1357-3039 (07)00205-8/abstract. Retrieved 2011-09-02.

[14] "Epidemiology of Poisoning". http://www.who.int/ipcs/poisons/en/. Retrieved 2011-09-02.

[15] "National Poison Prevention Week". http://www.medicinenet.com/script/main/art.asp?articlekey=12511. Retrieved 2011-09-02.

[16] “Acute pesticide poisoning: a proposed classification tool". http://www.who.int/bulletin/volumes/86/3/07-041814-table-T1.html. Retrieved 2011-09-02.

[17] “Different types of poisoning”. http://www.pinellas-park.com/Departments/fire/different_types_of_poisonings.asp. Retrieved 2011-09-02.

[18] Complete diving manual by Jack Jackson

[19] Chyka PA, Seger D, Krenzelok EP, Vale JA (2005). "Position paper: Single-dose activated charcoal". Clin Toxicol (Phila)43 (2): 61-87. PMID 15822758.

[20] "Position paper: whole bowel irrigation". J Toxicol Clin Toxicol42 (6): 843-854. 2004. Doi: 10.1081/CLT-200035932. PMID 15533024.

[21] Vale JA, Kulig K; American Academy of Clinical Toxicology; European Association of Poisons Centres and Clinical Toxicologist. (2004). "Position paper: gastric lavage". J Toxicol Clin Toxicol42 (7): 933-943. Doi: 10.1081/CLT-200045006. PMID 15641639.

[22] American Academy of Clinical Toxicology; European Association of Poisons Centres Clinical Toxicologists (2004). "Position paper: Ipecac syrup". J Toxicol Clin Toxicol42 (2): 133-143. Doi: 10.1081/CLT-120037421. PMID 15214617.

[23] Toxicology, American Academy of Clinical (2004). "Position paper: cathartics". J Toxicol Clin Toxicol42 (3): 243-253. doi:10.1081/CLT120039801. PMID 15362590.

[24] http://www.ispub.com/journal/the_internet_journal_of_emergency_and_intensive_care_medicine/volume_11_number_1_2/article/fatal_poiso ning_caused_by_oral_ingestion_of_a_hair_dye.html

[25] Information from A.VIJAYA KUMAR.,M.PHARM., DRUG \& POISON INFORMATION CENTER, KOVAI MEDICAL CENTER AND HOSPITAL, COIMBATORE-641014 DEPT: 0422-4323414, http://vijayspharm.googlepages.com. Retrieved on 2011-07-16.

[26] Ana L Huerta-Alardín, Joseph Varon and Paul E Marik. Review Bench-to-bedside review: Rhabdomyolysis - an overview forclinicians. 2005 April, Vol 9 No 2: Page no. 158, 163.

[27] Clinical management of poisoning and drug overdose, Haddad Shannan Winghester, W. B Sanuders company, 3rd edition.

[28] Kllenhorns medical toxicology, diagnosis and treatment of Human poisoning, Matthew J Ellenhorn, Willian and Wilkins publications, 2nd edition.

[29] "Poison control center", http://en.wikipedia.org/wiki/Poison_control_center. Retrieved 2011-09-20.

[30] Goldfrank LR, Flomenbaum NE, Lewin NA, Howland MA, Hoffman RS, Nelson LS, ed (2002). Goldfrank's toxicologic emergencies. McGraw-Hill. ISBN 0-07-136001-8.

[31] Miller T, Lestina D (1997). "Costs of poisoning in the United States and savings from poison control centers: a benefit-cost analysis". Ann Emerg Med29 (2): 239-245. Doi: 10.1016/S0196-0644(97)70275-0. PMID 9018189.

[32] The International Programme on Chemical Safety. "World directory of poisons centres". World Health Organization. http://www.who.int/ipcs/poisons/centre/directory/en/. Retrieved 2011-09-20. 